\title{
THE USE OF PUBLIC SPACES IN RELATION TO DOGS IN THE CITY OF DEBRECEN
}

\author{
ANTAL LOVAS KISS ${ }^{l}$
}

\begin{abstract}
In my study I present the urban environment as a space for walking a dog from the perspective of the dog owner. I analyze the activity of walking a dog as the most characteristic manifestation of the contact between public space and the dog owner, and using the method of mental mapping. I explore how dog owners perceive public space when walking their dogs. The initial hypothesis of my research was that dog owners use public spaces differently from others when they try to construct and satisfy the (assumed) needs of another creature from their viewpoint. During walks, owners use public spaces in a way that, according to their conception, suits their dogs the most. We could also say that they aim to use space from the dog's perspective, as they can conceive of this. Urban dog keepers vary in terms of motivation, dog-keeping practices and lifestyle, thus we cannot speak about them in general. However, through examining different individuals and groups it is possible to identify some features of the "dog lifestyle." This is important as there is a growing need to identify and understand this specific lifestyle model. In today's urbanism, the role of multifunctional spaces is increasingly significant as such spaces are being created not to the detriment of the different sub-social groups, but by taking specific needs into consideration.
\end{abstract}

KEYWORDS: mental mapping; dog walking; perspective of the dog; using urban space; urban dog owners

\section{PREFACE}

Everybody desires something. Some would like a parking space next to their house. Others would like to see parks when they look out of their windows, whereas people with kids desire more playgrounds. There are those who want

1 Antal Lovas Kiss Ph.D. is an honorary associate professor at the University of Debrecen, Faculty of Child and Special Needs Education, Department of Social Science, e-mail: lovaskiss@gmail.com. 
stores near their homes so they can immediately obtain what they want. Public spaces are the meeting hubs of these different, and sometimes diverse, needs and interests. One demand among many is that of the dog keepers' community for the use of public spaces. The present research focuses on urban life from the perspective of dog owners.

The central element of the study is walking, since I assume that walking a dog, as an everyday practice, is the most characteristic contact between the owner and the public space. In my investigation I studied this practice with the method of mental mapping and participant observation; the aim was to analyze how owners perceive public space through the act of walking. My hypothesis was that owners use public spaces differently from others as they use them with and for other beings: i.e. their dogs. Therefore, the routes of these everyday walks are designed from the imagined perspective of the dog. The mental maps of walks thus involve human conceptions of dogs' visual-spatial perception.

However, walks do not only involve owners and dogs. Keeping a dog in an urban environment is one lifestyle among many others, and when keepers step into a public sphere they necessarily become the object of other people's reactions. Consequently, there are two angles to this research: a desire (I) to better understand the relationship between owners and dogs, and (II) to describe the relationship between dog owners and the community.

As far as I am concerned, I hope this research will help to create more livable public spaces that support many different lifestyles. This specific study focuses on the first angle; namely, a description and understanding of the lifestyle of "urban dog owners," their habits, needs, and the way they perceive public spaces through their activity with dogs.

\section{METHOD}

According to the "spatial turn" in twentieth-century social science, space is neither static nor objective, thus there are several different ways of understanding its nature. Many theorists claim that space is a social construction that constantly changes through human activity. People produce and reproduce spaces and their meanings. In 1960, Kevin Lynch was the first to describe human spatial perception with the notion of mental and cognitive mapping. Lynch, and later Stanley Milgram (1972), saw cognitive maps as images that one inherently develops about a space. Individuals understand and arrange information about their environment through this cognitive and mental map (Downs et al. 1977). Cognitive maps are comprised of a person's subjective judgments and emotions about the given space (Didelon et al. 2011). 
The present research, which I carried out in the summer of 2017, is based on how dog owners construct their cognitive maps around their personal feelings and judgments of public spaces. To unfold these subjective judgments, I used different techniques such as the mental mapping of dog-walking routes. Keeping dogs in an urban environment is very popular nowadays, but there are substantial variation in how people walk their dogs. I assume that, due to their dogs, dog owners perceive public spaces differently. Spatial perception depends on how the perceiver uses the space. As the hypothesis assumes, how people perceive public spaces changes when they walk their dogs, as they would like to create the most optimal route for their animals. Mental mapping is suitable for describing subjective imaginations and attitudes towards certain spaces (Uszkai 2015), thus I applied to the study of dog owners' spatial perception.

I asked 18 informants, dog owners and inhabitants of Debrecen to draw a map of their everyday dog-walking route and attach comments to it. The informants were requested to make the map as if they were recommending it to other dog owners. Later, I also undertook structured interviews with the informants: this method generated a more precise picture of the owners' personal opinions than a simple questionnaire could. Besides, mental maps are not informative enough and their outcome also depends on the applied research method (Devlin 2001 in Mester 2007; Kiss 2005). For this reason, I used both visual and textbased techniques at the same time. As Barbara Tversky emphasizes, cognitive processes are very complex and often indivisible, thus the researcher must apply a complex method to unfold them (1993). A cognitive map is not only a picture of the physical space in our mind, but a complex mental representation (Wilhelm 2005).

The mental mapping in this research focused on the dog walking routes. The drawings mainly captured directions, not spaces, expenses, borders or hubs. Hence, the structured interviews concentrated on these missing features. Questions concerned the time of the walk, its duration, and how the owner developed the direction and the purpose of the walk. I wanted to know which places were considered appropriate for walking, and which factors could generate potential conflict between the owner and other users of the public spaces, and why.

For the present research, I also applied the method of field-site exploration. Instead of drawing a map, I accompanied two of my informants on their daily dog walks and asked them to comment on what they were doing and why. I was interested to know how the owners perceive the space in which they walk, what they pay attention to, what their memories about it are, and what the characteristics of the chosen route are. Field-site exploration is a more precise method of understanding informants' personalized cognitive maps and their 
actual environments at the same time (Mester 2007). According to George E. Marcus's concept of multi-sited ethnography (1995), ethnographers should follow the object of their research, since this grounds the field of research (Marcus 1995, 1986).

The present investigation is exploratory research that supports a wider and more complex study of the relationship between dog owners and their urban environment. Therefore, the data I obtained are not representative (they cannot be, as there is no information about the approximately 25,000 dog owners in Debrecen in any database; Kemecsei 2015). As we are not able to collect data about walking habits, my data may not represent dog owners' attitudes more generally. For instance, three out of the twenty informants said that they put their dog's excrement into trash cans. However, this proportion does not represent the situation in the city center. (Interestingly, these kinds of questions and answers indicate how informants try to show that they conform to social norms, even if they do not keep to these rules in reality.) In addition, this exploratory research may show some of the individual tendencies involved in owning a dog, and thus suggest further directions for investigation.

I identified my informants from a local dog school. I assumed that people who regularly attend such lessons are liable to pay attention to their dogs' needs consciously. This group, however, does not represent the entire community of dog keepers in Debrecen. Hence, as control factors I also questioned some dog owners who were not attending a dog school. The location of the investigation was the city of Debrecen in Hungary. The research did not focus on one commonly frequented space in the town, but more on the act of walking with the dog as one specific way of using public spaces. All the mental maps that my informants made represented different parts of Debrecen.

As I have already mentioned, there are many limitations to the present research. This study does not deal with the different social backgrounds and lifestyles of the owners, or the effect of these factors on walks. My data mainly refer to middle-class dog keepers. Also, this exploratory research could not deal with a very important issue in the wider research effort; namely, the relationship between the dog owners and other people in public spaces and the wider environment. This may be the subject of further investigation. 


\section{RESULTS}

\section{Mental mapping and structured interviews}

The analysis of mental maps is a very complex process which the current article does not attempt to fully explain. The present chapter concentrates only on the factors that shape the dog owners' chosen walking routes. From an anthropological standpoint, we could say that walking a dog is a stereotypical, repetitive habit, thus I assumed that this process could be a suitable basis for an ethnographic description. In contrast to this assumption, when my informants made their maps, they described their walking as an ever-changing process ("We always take different routes.") This variability caused difficulties with the analysis of the mental maps. Most of the informants use the same areas for walking, but they often changed the length of walks. Sometimes the owner and the dog take a longer route, and at other times a shorter one. Most of the informants drew all their routes on the same map (Pictures 1 and 2).

Normally, when people draw mental maps they construct them according to the target of their routes. It is the opposite in the case of dog walking, because the purpose of the walk is walking itself. This is the reason why owners pay more attention to the locus of the walk and aspects such as busyness, streetlights, and public security. The mental maps illustrated these routes, but the drawings were not informative enough to reveal correlations between the different loci. The structured interviews, however, revealed these correlations. For instance, those who took different routes of different lengths said that the length of the walk depended on the available time. Before work, owners choose a shorter route, but after work, in the evening, they have sufficient time to go on a longer walk. There is also a difference between weekdays and weekends. At weekends, owners go for longer and more intense walks when they can do more activities with their dogs. (As most of the informants are members of the local dog school, they do the same activities in the lessons.)

The informants also revealed what the most important factors are that influence the direction of the walks. For most owners, the main issues were the weather and the length of the route, but some of them decided on their route by chance or due to their feelings. ("If I am tired, we take the shorter route.") Interestingly, the location of walks seems to be very changeable over time. Most owners said that they had made a big effort to obtain their dog as a puppy and had reconstructed their living space to be comfortable for the dog, but none of them constructed the route of their walks in advance. Therefore, they had to adapt to the given urban environment gradually. All the owners claimed that they had had to change their route several times because of the environment. 
The most significant parts of the maps are the directions. My hypothesis before the interviews was that the routes would have different meanings for owners when they navigate them with or without dogs. I also assumed that this difference would be measurable on the mental maps, as the owners would distinguish between the desire of the dog and their own desires. However, from the maps this factor was not found to be significant. The owners visualized these differences through only a few signs (e.g. the representation of grass, trash cans, pedestrian crossings, dangerous sections, nice dogs). In contrast to my hypothesis, only a few people tried to "think like their dogs" when they planned the direction of walks. Individuals were more likely to design the routes to meet their own needs and timetables. It was more common that individuals marked places on the map which were important to them personally (banks, shops, churches, etc.) (Pictures 3 and 4).

\section{Walking a dog as a form of self-representation}

I identified an interesting practice during the data collection process. The members of the dog school go for collective walks with their dogs. On summer afternoons and evenings, the school members and their dogs walk through the city centre's most popular parts where there are bars and restaurants. They take these walks not to fulfil the dog's needs, as the dogs are on leashes during the whole time, but to present how disciplined their dogs are. These walks are designed to demonstrate to local people that dogs can be present in any public spaces without any problems (Gyáni, 1990). Such events are planned, but the directions of the route take shape spontaneously (Picture 6).

One of the members of this group drew a map. The fixed point of the walks is a meeting point: a pancake restaurant in which dogs are allowed. In contrast to the normal dog walking routes, the primary issue here was not the direction of the walk: the informant only specified the potential direction of the walk, not the actual route, as this always changes (Picture 5).

\section{Joint walks with research participants in different field sites}

My analysis of the given mental maps was centered round the direction of walks. As opposed to this, in the case of the exploration of field-sites I wanted to describe the data in terms of owners' control of their dogs. In public spaces, one of the most important issues is controlling dogs, as such spaces are shared areas for different people with different attitudes towards dogs. This is an issue that 
cannot be visualized on a map, but is the key element of participant observations. In the case of walks, it is essential to keep dogs under control for two main reasons: First, it is important for the dog's own safety near busy city streets. Second, in the process of walking public spaces become "semi-public spaces" for owners and dogs as their use is connected to specific legislation. According to one such law, dogs in public spaces in the city must wear a leash (Government regulation 41/2010. 17§ (1)). Even if owners do not comply with the legislation, this situation influences walks. Consequently, the method of participant observation was considered appropriate for describing the relationship between dogs, owners and public spaces through the notion of control.

I followed two informants on their everyday walking routines. During the walk, the owners shared their experience with the locus and, as we went along the route, had a chance to demonstrate them (Mester 2007). Field-site exploration, without doubt, was the most appropriate method for investigating the walks, including their motivations and the owners' usage of the given space. First, the keepers described what the most suitable route was for them. The best routes were those that were visible to keepers at a distance of at least ten meters. Consequently, they could see all potential difficulties such as pedestrians and vehicles. In some cases, when the owner could not avoid nearing a difficult section, they had to minimize potential conflict. They did this by restricting the dog's personal space. In the case of my informant, the strongest form of control was the spoken command "to me," which the owner had learnt at dog school. This strong form of control was needed only in a few cases - at crossroads, on busy streets, and while walking through a shopping center. (An informant said during the walk that owners could nowadays enter malls with their dogs. When he saw I was surprised by this fact, he demonstrated it to me and said he and his dog often do this when they would like to shorten their walk home) (Picture 7).

Similarly to owners, dogs also pay attention to potential risks as they have learnt about these on their relatively repetitive walks. Therefore, they automatically initiate the "to me" practice in uncertain situations. Even while the owner and the dog are prepared for various situations, they sometimes have to change their route if there is no other way to avoid a conflict (e.g., during my investigation, in a narrow street with too many pedestrians, and also when the owner and dog met an unfamiliar dog).

The application of control was different in the case of the two informants. One used a flexible leash with a maximum length of five meters, while the other walked his dog without a leash. In the first case, the length of the leash reflected how safe the owner felt on that particular section of the route. When he sensed a potential risk, he made the leash shorter. As for the owner who did not use a leash, the route was in a suburban district without significant traffic. In spite of 
the fact that this form of walking seemed to be most uncontrollable, it rather involved a more complex level of control. All the time the owner interpreted what he was doing and why he was doing certain things. The dog had attended training for five years and knew the place he was walking well, thus the owner walked confidently with the dog at a 5-10 meter distance. This distance was enough for the keeper to intervene in the case of possible risk (Pictures 8 and 9).

As I found out, there are some typical sources of risk for owners during walks. Open gates and front doors could mean potential danger, as could other dogs or vehicles, while the owners' dogs could enter houses as well. Another problem involved the risk of dogs destroying the flower gardens in front of houses, in which case the landlord could forbid the owner from walking there in the future. Sometimes pedestrians were frightened of the dogs. Therefore, street corners around which the owners do not know if people might becoming represent another source of risk. As a result, owners have to pay attention to multiple factors during their walks. There are many risk sources for dogs in public spaces such as vehicles, other dogs, or pedestrians who do not trust dogs for any reason (Pictures 10 and 11). Another thing that owners have to keep in mind is the legislation pertaining to the locus of the walk. (My informant walked without using a leash even through legislation forbade this.) The last group of risk sources includes anything that might frighten the dog. Owners have to avoid all factors that could be harmful to their dogs.

\section{CONCLUSION}

\section{The correspondence of the method with the results}

The present exploratory research generated many different results. The results of the field-site exploration suggest that owners try to think from their dog's perspective during their everyday walks. In contrast, the results of the mental maps were the opposite. There are several possible reasons for this difference.

On the one hand, the method of mental mapping has a focus different from that of field-site exploration. When my informants were asked to draw their routes, they made an attempt to summarize their everyday practice on one sheet. Since they highlighted the essential parts, they universalized their walking route. On the other hand, the field-site exploration gave a subtle picture of ungeneralizable, sudden situations. During this form of investigation, I had a chance to observe how owners and their dogs perceive their environment as "phenomenal reality." In other words, during the process of mental mapping, the informant generalizes the perceived space and activity ("I do this in general"). 
However, the method of field-site exploration is more like an event ("this is how I am doing it now").

Another reason for the differences is the informants' intentions. Mental maps are interpretations that the informants construct for the researcher. For this reason, they use human language for the explanations, not the signals that they use with their dogs. The maps show walks that are designated for dogs, but without the involvement of the dogs.

The third reason is that small-sized dogs on a leash become a part of the owner's body (Merleau-Ponty 1945 [2014]), hence owners can use their own cognitive maps without the influence of the dog. The informant who walked his dog without a leash during the field-site exploration had the opposite experience. Although the dog's position was directed by the former, the dog was permitted a relatively wide space to move freely. It was this form of walking that involved the most intense interplay between the owner and the dog, and a high degree of attention and control.

\section{Results in the context of theory}

To analyze the results of mental maps, I used Edward W. Soja's theory of trialectics. According to Soja's theory (1996), I divided the space of the dog walks into three components - objective space, conceived space, and lived space.

Objective space is basically empirical. In the case of the present investigation, this is the urban environment that architecturally establishes the use of the space. This is well-defined - it is the space where locals can walk, drive, play, rest, etc. Cities are also spaces where different and diverse lifestyles must coexist, and public spaces are their representative loci. Nowadays, because of consumer culture and its economic arrangements, public spaces have to satisfy different needs. Walking dogs in public spaces is a practice whereby owners and dogs become manifest to other people. A walk in this sense is one specific way to consume public space. Dogs have special needs, such as parks, special trash bins, city lights, etc. that public spaces cannot always satisfy, as one of my informants complained. However, there are not only the needs of dogs and owners, but also expectations toward them. Dogs have to be safe with respect to people, and owners have to keep parks clean after their dogs (Picture 12).

The second dimension of space is conceived space. This is formed in the mind (i.e. is an entirely mental space). In this dimension, all individual experiences about space are subject to subjective filters (Makádi 2012). Through mental mapping, I made an attempt to obtain data about this mental representation. 
Every time we speak about public spaces, we must also speak about power. The notion of power is even more relevant in the case of urban environments, as they are mostly juridically and politically governed, unlike mere geographical places. As Foucault says, cities are fields governed by power (Foucault 1980). When dealing with urban dog keeping and walking in public spaces, we must thus also consider the issue of power. Owners should keep their dogs under constant control outside their private property, and they must do this because of legislation. Control over dogs is an iteration of control over owners by law.

Mental spaces are designed by the current power structure (Lefebvre 1991; 1996). Power defines for human beings (or, in this case, for dogs) where they are allowed to go and where they are not. In Debrecen, the only method local authorities have of controlling dog keepers is to limit the playing fields of dogs. Because of legislation, public spaces become semi-public spaces for dogs and their owners, but dogs can only use these areas if they are wearing a leash and muzzle, although many other spaces are not open to them at all.

According to Soja, the third aspect of space is lived space. This form of space opens up the possibility to circumvent power as it is outside the scope of power. Many of my informants, but mainly those who owned a small-sized dog, had no problem with the related legislation and easily complied with it. In contrast, those who had larger dogs typically did not like these rules since they narrowed their capability of moving. Therefore, they broke or ignored these laws. Many informants felt that they could not satisfy their dog's biological needs if they walked them on a leash. As a result, these informants developed their own special strategies for circumventing the law. They go for walks early in the morning or late at night when streets are not busy. Others use parks only in winter when other people do not normally use them.

During my investigation, I found one unique method by which owners break the rules regarding leashes. This is the demonstrative dog walk that the local dog school conducts in summertime. When the members and their dogs walk across the city centre without a leash, they are seeking to demonstrate how welleducated dogs can exist in the public sphere without causing any harm to others. They thus represent self-control, instead of juridical control. Owners do these walks because they have realized that public opinion about dogs depends on how they represent the latter's obedience. These dogs serve as a counter example to the widespread image of the "uncontrollable dog." The work of these members is very important, as in certain places, especially in Hungary, no dogs - not even assistance dogs - are allowed.

The former group's public activities are demonstrative and symbolic at another level. They are a part of a trend which started in the early twenty-first century and which has gradually emancipated the community of dog keepers in public 
spaces. The field-site exploration gave me an opportunity to follow dog owners into places which had not been open to dogs before, such as shopping centers. As a part of this trend, places that first accepted dogs are called non-places by Marc Augé (1992). Non-places refer to spaces that do not have enough significance to be regarded as places, such as places of trade, supermarkets, hotels, airports or motorways. Nowadays, this change in the use of public spaces is taking place, but slowly. Some places are already open, but others are not. As one of my informants explained, "I can go shopping with my kids and dog, but not go to the playground." In this process, the most difficult thing to change is access to spaces that are already a part of social memory. Therefore, the dog walks by the training school in the city center of Debrecen are of special importance as they involve a "conquest" of these spaces.

The present research was designed to give a glimpse into a specific form of use of public spaces. I assumed that there was one decisive difference in this regard between dog owners and non-owners: for those who walk with their dogs, the use of public spaces is limited - for example, by regulations.

There are several difficulties involved in the investigation of urban dog keepers in Debrecen. We cannot speak about these individuals more generally as they are a heterogeneous community. We cannot even perceive of them as a group, because they organize themselves rarely, and mostly locally. However, a dogkeeper lifestyle exists, and the needs of this group are becoming increasingly visible in modern urban planning.

For such modern urban planning, the creation of "multifunctional spaces" is central, as policymakers should take into account the demands of various social groups. The present explanatory research may be of use in urban planning by explaining owners' perspectives and needs. This knowledge may help create more livable public spaces.

Further investigations should focus on four variables: the owner, the dog, the environment, and power. These are the external and internal aspects related to dog keeping. Internal aspects, for example, include the attitude of owners towards their dogs, and the needs of dogs, which are derived from the breed's characteristics or the dogs' own temperament. External aspects include national and regional legislation and the design of the urban environment (residential density, parks, local society, etc.).

\section{REFERENCES}

Augé, Marc (1992), Non-Places. Introduction to an Anthropology of Supermodernity (Translated by Howe, J.), London, Verso 
Devlin, Sloan Ann (2001), Mind and Maze. Spatial Cognition and Environmental Behavior, Westport, Praeger

Didelon, Clarisse et al. (2011), "A World of Interstices: A Fuzzy Logic Approach to the Analysis of Interpretative Maps", The Cartographic Journal, Vol. 48, No 2, pp. 100-107.

Downs, Roger - Stea, David (1977), Maps in Minds: Reflections on Cognitive Mapping, New York, Harper and Row

Foucault, Michel - Colin Gordon (ed.) (1980), Power/Knowledge. Selected Interviews and Other Writings 1972-1977. New York, Pantheon

Gyáni Gábor (1990), "A városi mikroterek társadalomtörténete" [The Social History of the Urban's Micro Spaces], Tér és Társadalom [Space and Society] No 1, pp. 1-15.

Kemecsei Zsuzsa (2015), Huszonötezer kutyát kell nyár közepéig összeirni Debrecenben. [Twenty-five Thousand Dogs Must Be Recorded in Debrecen by Mid-summer] https://www.dehir.hu/debrecen/ebosszeiras/2015/01/16/ (2019. 03.09.)

Kiss János Péter (2005), “A mentális térkép" [The Mental Map], in Nemes Nagy József, ed., Regionális elemzési módszerek [Regional Analysis Methods], Budapest, ELTE Regionális Földrajzi Tanszék MTA-ELTE Regionális Tudományi Kutatócsoport, pp. 96-98.

Lefebvre, Henri (1991), The Production of Space (Translated by NicholsonSmith, D.) Oxford, Blackwell

Lefebvre, Henri (1996), Writings on Cities (Translated and ed. by Kofman, E. Lebas, E.). Oxford, Blackwell

Lynch, Kevin (1960), The Image of the City. Cambridge, MA, MIT Press

Makádi Mariann (2012), "A tanulók Európa-képzete. Egy térbeli intelligencia felmérés tapasztalatai" [The students' Europe notion. Experiences of a spatial intelligence survey], A Földrajz Tanitása [The Teaching of Geography ], 20(4), pp. 3-14.

Marcus, George E. (1986), "Contemporary Problems of Ethnography in the Modern World System", in Clifford, James - Marcus, George E., eds., Writing Culture. Berkeley, University of California Press, pp. 165-193.

Marcus, George E. (1995), "Ethnography in/of the World System. The Emergence of Multi-Sited Ethnography", Annual Review of Anthropology, Vol. 24, pp. 95-117.

Merleau-Ponty, Maurice (1945), Phénoménologie De La Perception. Paris, La Librairie Gallimard, NRF, Magyarul: Merleau-Ponty, Maurice (2014), Az észlelés fenomenológiája [Phenomenology of Perception], Budapest, L'Harmattan

Mester Tibor (2007), “Mentális térképezés”[Mental mapping], in Kovács Éva, ed. 
Közösségtanulmány. Módszertani jegyzet [Community Study. Methodological Notes], Néprajzi Múzeum, Budapest, PTE-BTK Kommunikáció- és médiatudományi Tanszék, pp. 296-316.

Milgram, Stanley (1972), “A Psychological Map of New York City”, American Scientist, Vol.

60, pp. 194-204.

Uszkai Andrea (2015), "Fizikai és mentális határok a társadalmi térben, a mentális térképezés elméleti háttere és gyakorlati kutatásai” [Physical and Mental Boundaries in Social Space, the Theoretical Background of Mental Mapping and Practical Research], in Hardi Tamás, ed., Terek és tér-képzetek: Elképzelt és formalizált terek, régiók a Kárpát-medencében, KözépEurópában [Spaces and Space-notions: Imagined and Formalized Spaces and Regions in Carpathian Basin, and in Central Europe], Somorja, Györ, Fórum Kisebbségkutató Intézet, MTA KRTK Regionális Kutatások Intézete, pp. 155-164.

Soja, Edward W. (1996), Thirdspace. Journeys to Los Angeles and Other Realand-Imagined Places. Oxford, Blackwell,

Tversky, Barbara (1993), "Cognitive Maps, Cognitive Collages and Spatial Mental Models", in Frank, Andrew U. - Campari, Irene, eds., Spatial Information Theory: A Theorethical Basis for GIS. Proceeding COSIT'93, Berlin, Springer, pp. 14-24.

Wilhelm Gábor (2005), "Kognitív térképek és városreprezentáció" [Cognitive Maps and Urbanrepresentations], in N. Kovács Tímea - Böhm Gábor-Mester Tibor, ed., Terek és szövegek. Újabb perspektívák a városkutatásban [Spaces and Texts. New Pespectives in Urban Researches]., Budapest, Kijárat, pp. 2946. 


\section{PICTURES}

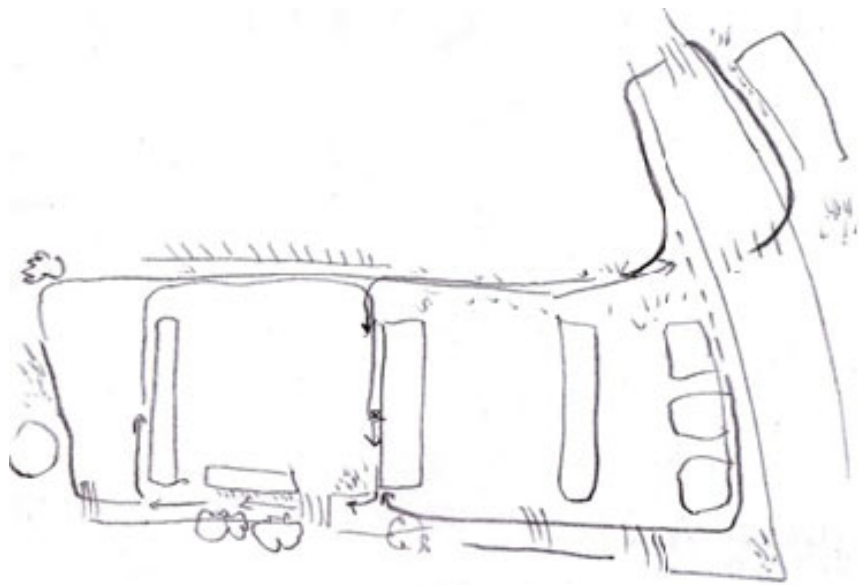

Picture 1 Multiple walking routes in one map, including pedestrian crossings, trees, grass and blocks of flats (drawing made by a young man who walks a small dog)

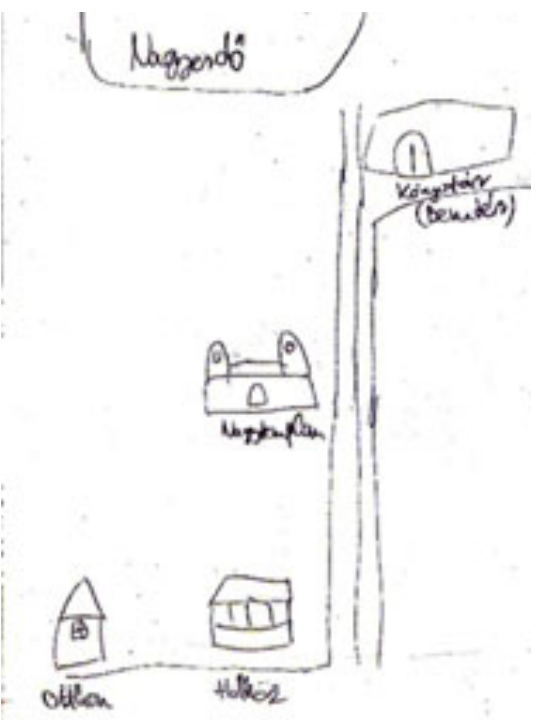

Picture 2 Illustration of a one-directional walk with characteristic buildings in Debrecen (drawing made by a young man who walks a medium-sized dog) 


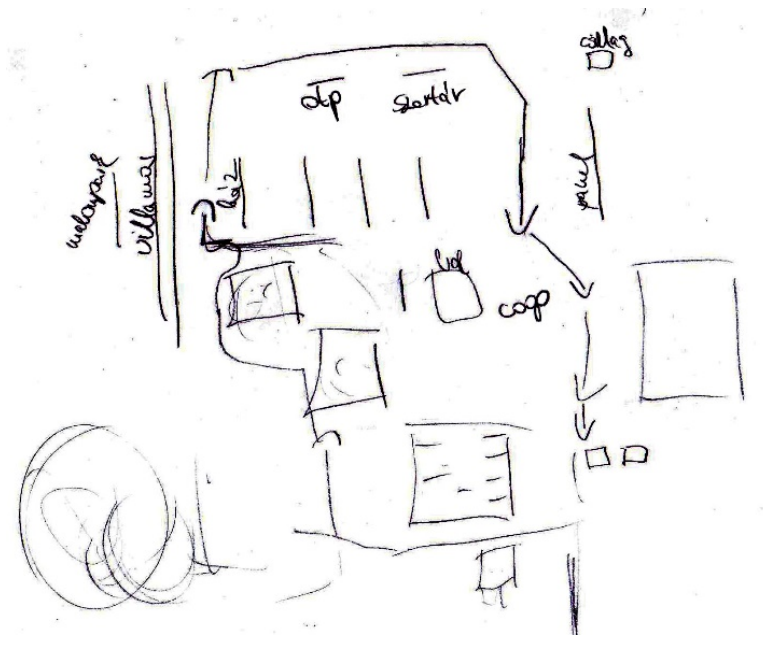

Picture 3 Directions for a walk with shops, bank, tram and blocks of flats (drawing made by a young woman who walks a small dog).

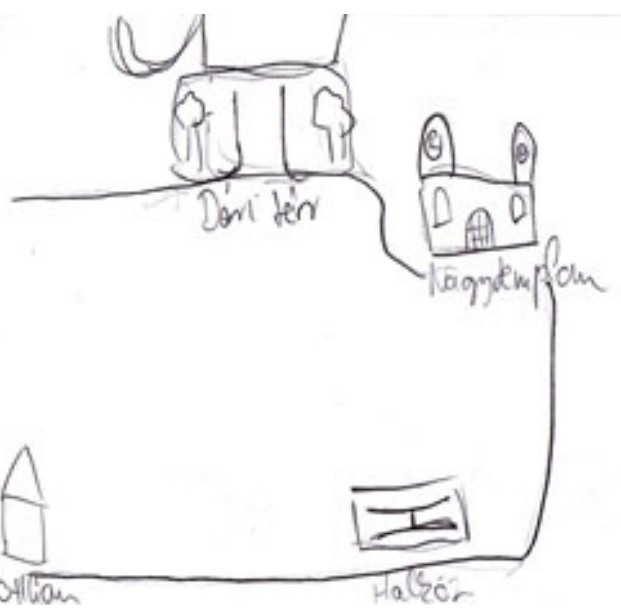

Picture 4 Symbolic buildings in Debrecen as reference points (drawing made by a young man who walks a medium-sized dog). 


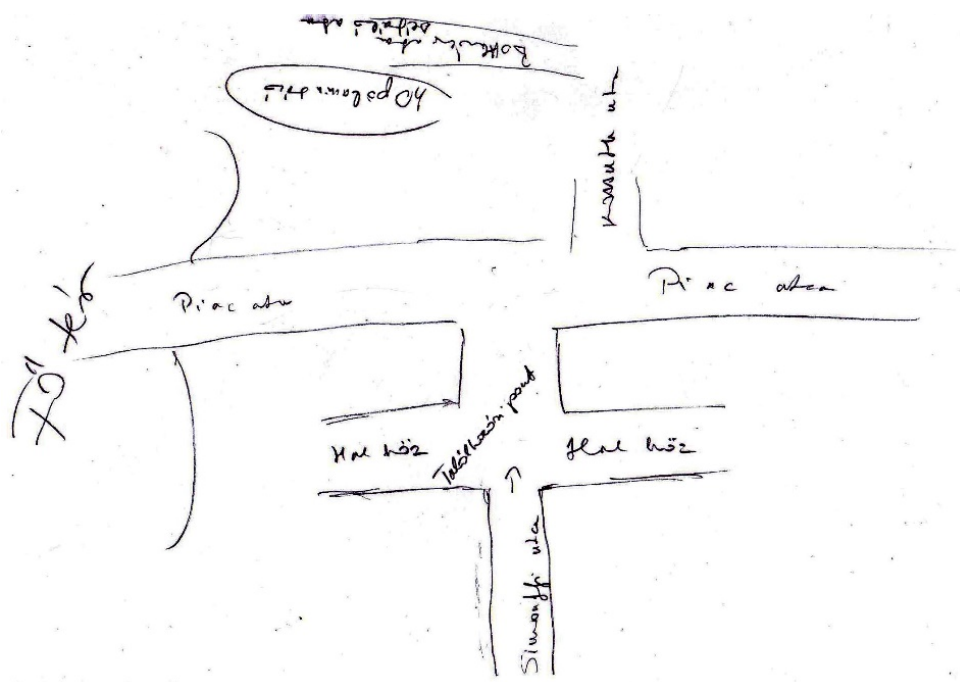

Picture 5 Group dog walking in the city center. In the upper part of the picture (upside-down) the pancake restaurant where dogs are allowed is marked (drawing made by a middle-aged woman who walks two small dogs).

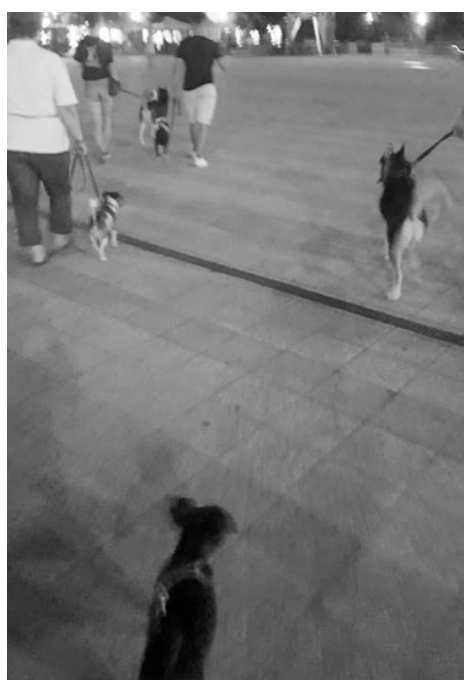

Picture 6 Procession with dogs in the main square (photo taken by a participant) 


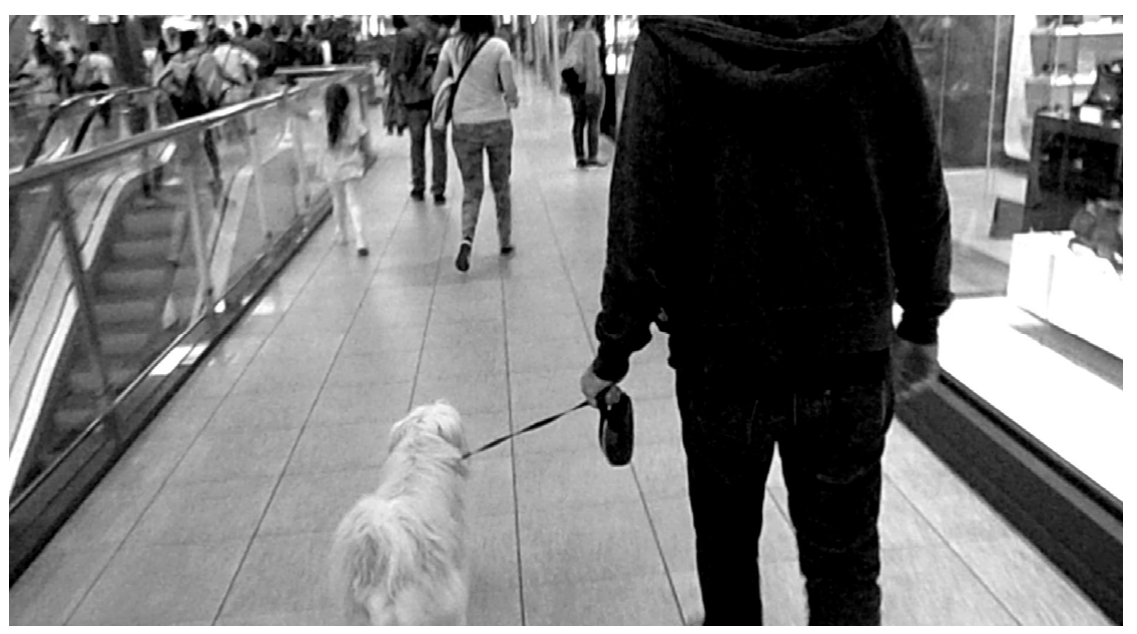

Picture 7 With a dog at a shopping center (photo taken by the author)

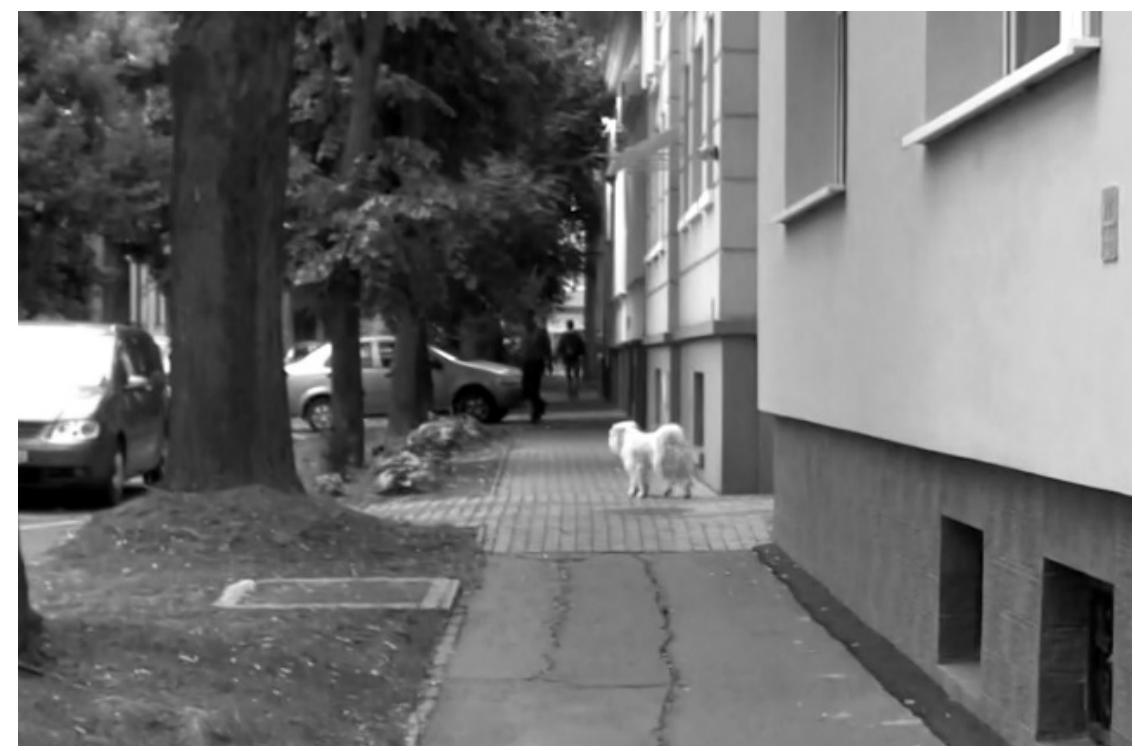

Picture 8 Dog waiting for its owner because of pedestrians (photo taken by the author) 


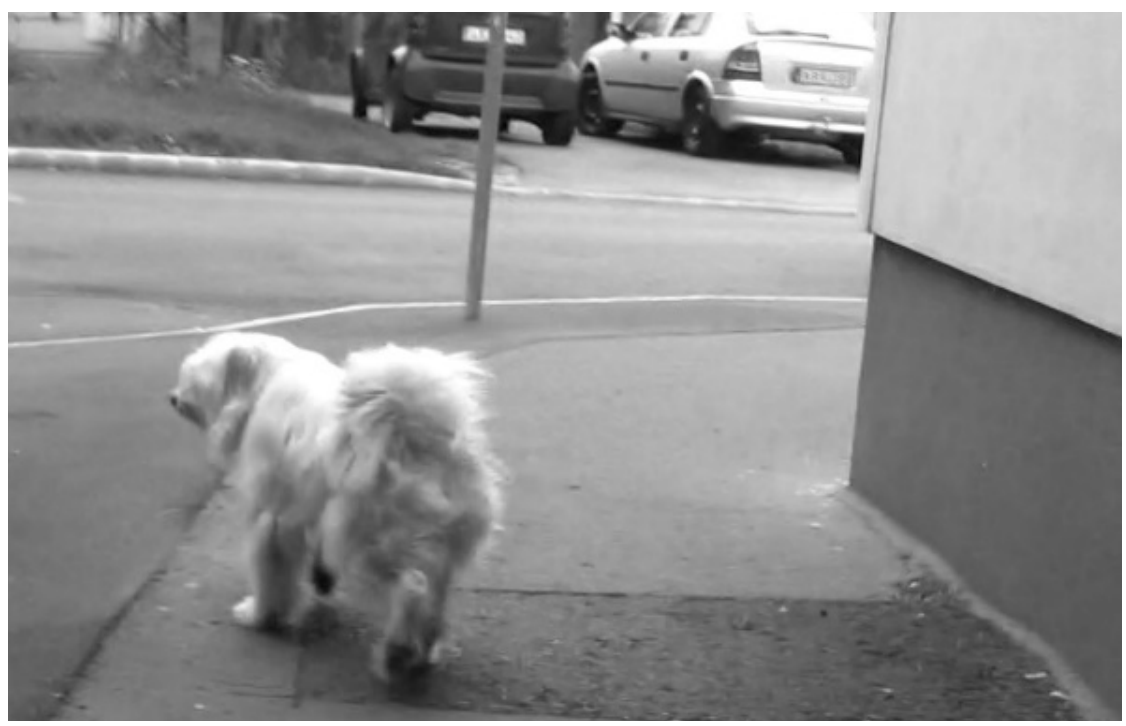

Picture 9 Dog stopping before a corner (photo taken by the author)

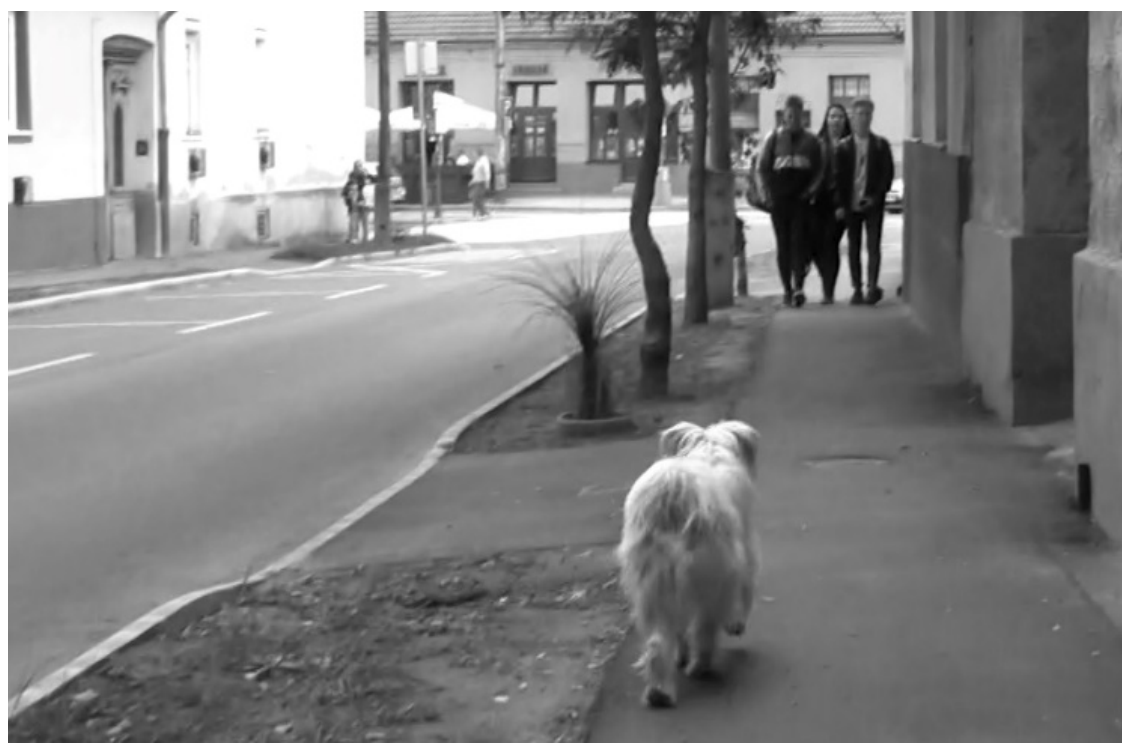

Picture 10 In traffic (photo taken by the author) 


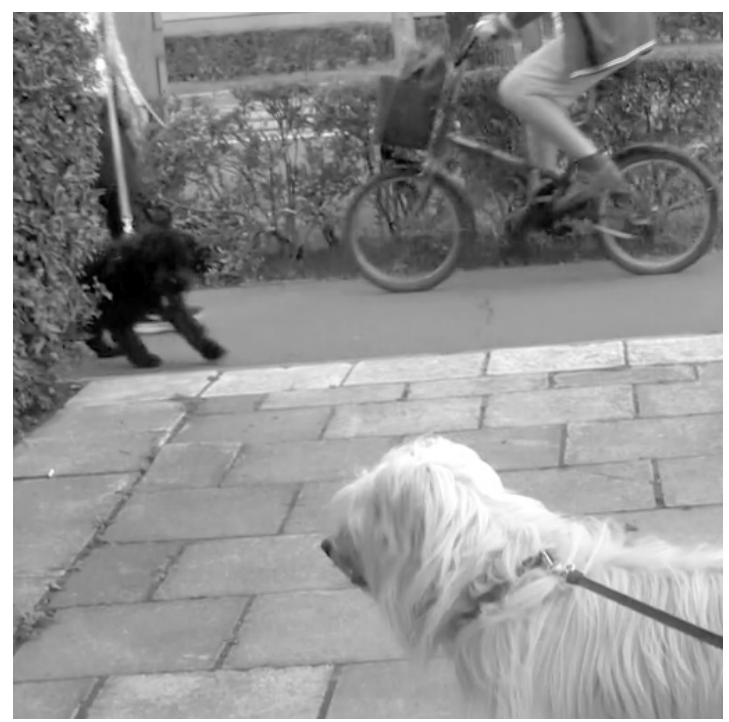

Pictures 11 In traffic (photo taken by the author)

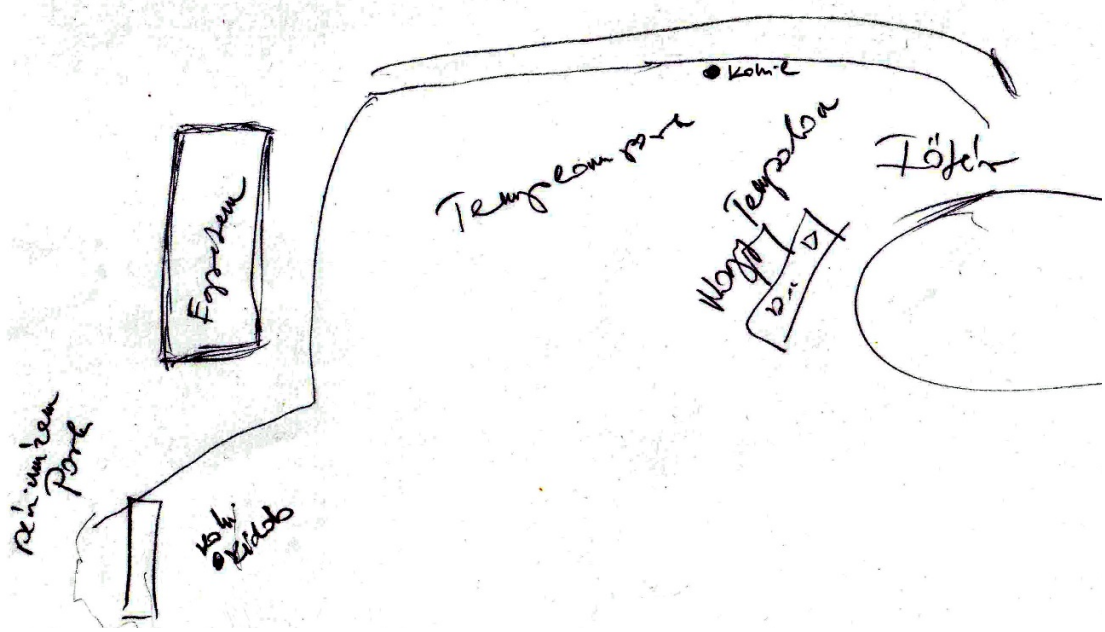

Picture 12 Owner's drawing of the approximately 500-metre route that she has to take to find a trash can for her dog's excrement (drawing made by a middle-aged woman who walks a small dog) 
